\title{
A Dél-Dunántúl fémdarázs faunája (Hymenoptera: Chrysididae)
}

\author{
JóZAN ZsOLT
}

\author{
H-7435 Mernye, Rákóczi F. u. 5.
}

e.mail: jozan.zsolt@citromail.hu

\begin{abstract}
JózAN, Zs.: Fundamental data of the chrysid (cuckoo) wasp fauna of the South-Transdanubia, Hungary (Hymenoptera, Chrysididae).

Abstract: Author lists the Chrysididae species collected in Southern Transdanubia in the last five decades. He also took into account the results of the Chrysididae revision carried out by Muskovits J. Table 1. contains the list of species and number of collecting sites of the various landscapes. The 123 species collected in Southern Transdanubis are $72 \%$ of the total number of species known from Hungary. Genera Chrysis and Chrysura are the dominants, $75 \%$ and $80 \%$ of Hungarian species were listed of these 2 genera. Table 2. shows the percentual distribution of the Chrysidyd species according to their zooography. Table 3. shows the percentage distribution of eco-faunistic characters of the species and table 4. shows the Jaccard indices of the investigated landscapes. Finally, in Table 5., the plants are listed visited by various Chrysidid species completed with the collected number of species from each plants. New species for the Hungarian fauna: Chrysis brevitarsis. Ch. calrinicollis, Ch. grohmanni krkiana, Ch. leptomandibularis, Ch. schencki, Ch. solida, Ch. taczanovskii. Ritka fajok: Elampus bidens, Hedychridium chloropygum, H. elegantulum, H. zelleri, Pseudomalus triangulifer (Elampini), Chrysis brevitarsis, Ch. chrysoprasina, Ch. gribodoi spilota, Ch. grohmanni krkiana, Ch. phryne, Ch. placida, Ch. pulcherrima, Ch. schencki, Chrysura hirsuta, Pseudospinolia uniformis, Spinolia unicolor (Chrysidini). A következő fajok magyarországi lelöhelyeinek jelentős része Dél-Dunántúlon van: Hedychridium elegantulum, H. monochroum, H. valesiense, Chrysidea disclusa, Chrysis distincta, Ch. germari, Ch. gracillima, Ch. graelsii, Ch. grohmanni, Ch. leachii, Ch. leptomandibularis, Ch. ragusae, Ch. taczanovskii, Chrysura trimaculata, Pseudospinolia uniformis.
\end{abstract}

Keywords: chrysid wasps, new records, rare species, flower visiting, Hungary

\section{Bevezetés}

A szerző több mint öt évtizede rendszeresen folytat gyüjtőmunkát Dél-Dunántúlon a fullánkos hártyásszárnyúak (Hymenoptera, Aculeata) körében. Az utóbbi néhány évtizedben Józan Zsoltné is bekapcsolódott a terepmunkákba. Minden évben számos terepnapon folytatták tevékenységüket. Majdnem háromszáz településen és környékén gyüjtötték a fullánkos fajokat, köztük jelentős számú fémdarazsat (Chrysididae) is. A munka eredményeképpen e család mintegy 4000 példánya került a Rippl-Rónai Múzeum (Kaposvár) rovargyüjteményébe. Az előkerült fajokról és lelőhelyeikről a szerző már számos közleményben számolt be (JózAN 1992a, 1992b, 1998, 2000, 2001, 2003, 2006, 2015), de ezek csak egy-egy kisebb területre szorítkoztak. Az utóbbi években Muskovits József revideálta a magyarországi fémdarázsfaunát. Feldolgozta a Magyar 
Természettudományi Múzeum teljes anyagát. Emellett négy másik múzeum gyűjteményét is áttekintette, közte a Rippl-Rónai Múzeum több mint hatezres anyagát is. Munkáját segítette Paolo Rosa specialista is. Munkáját a szerző rendszeres közreműködésével folytatta. Eredményeit egy terjedelmes kéziratban bocsájtotta rendelkezésünkre. Ebben részletes határozókulcsot állított fel és fajjegyzéket közölt a szinonímákkal. A fajok lelöhelyeit is felsorolta (MuskoviTs et al. manuscript). Ezek alapján tudtuk felülvizsgálni a Dél-Dunántúlon elökerült, a Chrysis ignita csoportba tartozó fajok példányait, továbbá figyelembe venni a vizsgált területen elökerült valamennyi fajt. A teljes fajjegyzéket az 1. táblázatban szerepeltetjük. A ritkább fajokról rövid jellemzést adunk. Röviden ismertetjük magyarországi elterjedésüket és dél-dunántúli lelőhelyeiket. A figyelembe vett terület a Zalai-dombság keleti részétől a Szekszárdi-dombságig, illetve a Balatontól a Dráváig tart, beleértve a Mecseket és a Villányi-hegységet.

\section{Eredmények és megvitatás}

Dél-Dunántúlon előkerült fémdarázs fajok és lelöhelyeik száma - a kiterjedt és hosszú idejű gyüjtőmunkának köszönhetően - jelentős. Sok faj hazai lelőhelyeinek tekintélyes része itt van. A fémdarazsak mindhárom alcsaládja elökerült a vizsgált területen. Az Elampini nemzetség mind a nyolc genuszát megtaláltuk, de a Chrysidini nemzetség tíz genusza közül a Praestochrysis, a Spintharina és Stilbum genusz került elö. Ezek fajai Magyarországon nagyon ritkák. A Magyarországon kimutatott 171 fajból 123 (72\%) került elő Dél-Dunántúlon. A Cleptinae alcsalád 11 magyarországi fajából csak 5-öt találtak meg (44\%) a vizsgált területen. A Cleptes fajok ritkán kerülnek elő, a Rippl-Rónai Múzeum gyüjteményében csak kevés példánya van. A Chrysidinae alcsalád Elampini nemzetségének hazánkban 63 faját tartjuk nyilván. Dél-Dunántúlon ezek közül eddig 44-et (70\%) mutattak ki. A 6 Hedychrum fajunkból 5 előkerült a vizsgált területen. A Holopyga fajok 70\%-át és a Hedychridium fajok 67\%-át sikerült kimutatni. Az Omalus, Pseudomalus és Philoctetes (továbbiakban Omalus s.1.) fajok háromnegyede került elö. Az Elampus fajok csak mintegy kétharmadát (63\%) sikerült a vizsgát területen megtalálni. A Chrysidini nemzetség Magyarországon ismert fajszáma 99. Dél-Dunántúlon ebböl 72 (73\%) került elő. A Chrysis fajok száma hazánkban 76, Dél-Dunántúlon ebből 57 vált ismertté (75\%). A Chrysura fajok $80 \%$-át sikerült gyüjteni. A kis fajszámú nemek közül csak a fentebb már említett hármat nem tudtunk a vizsgált területen kimutatni. A Spintharina versicolor előfordulására a Szársomlyó déli oldalán (Villányi-hegység) számítani lehet.

Elemzésünkben Dél-Dunántúl négy táját veszünk figyelembe. A legtöbb faj KülsőSomogyban került elő (106). Itt gyüjtöttünk a legtöbb alkalommal, és a múlt század közepén a Balaton menti településeken elödeink is többször megfordultak. Második helyen van Belső-Somogy 85-, majd a Mecsek következik 77 és a Zselic 73 fajjal (1. táblázat). A Zselicben nem került elő Cleptes faj, a Mecsekben is csak egy. A Hedychridium fajok részesedése Belső-Somogyban a legalacsonyabb, a másik három tájon majdnem egyenlő. A Hedychrum fajok száma a négy vizsgált tájon csak lényegtelen eltérést mutat. A Holopyga fajok részaránya a Mecsekben a legnagyobb, a másik három tájon lényegében megegyezik. Az Omalus s.l. fajok részesedése tekintetében a négy táj közti különbség elhanyagolható. A legnépesebb Chrysis nem fajainak részaránya a Zselicben a legmagasabb. Az előkerült fajok $54 \%$-a ebbe a nembe tartozik. A másik három tájon ezek részesedése nem éri el az 50\%-ot. A Chrysura fajok számaránya a Mecsekben a legmagasabb (8\%), a többi területen ez csak 5-6\%. 
A széles elterjedésű fajok (paleartikus, nyugat-palearktikus) részesedése a négy terület faunájában 50 és 53\% között változik. A legmagasabb Belsö-Somogyban és a Mecsekben. A déli elterjedésű (mediterrán) fajok részaránya 44 és $46 \%$ között változik. a különbség alig több 1\%-nál. Külső-Somogyban és a Zselicben kissé meghaladja a 45\%-ot. (2. táblázat).

A fémdarazsak túlnyomó többsége melegkedvelö faj. A nyári hónapokban rajzanak. A Chrysura fajok között találjuk a tavasszal repülő fajok zömét. A Chrysura trimaculata imágói néha már március végén megjelennek. A Chrysis fajok között a legkorábbi a Ch. mediata, áprilisban már találkoztunk vele. A jellemző rajzási idejük júniustól augusztus végéig tart. A négy vizsgált táj fajainak mintegy $80 \%$-a melegkedvelő (eremophil). Számottevő különbség nincs közöttük, legmagasabb a Mecsekben és lagalacsonyabb a Zselicben. Lényeges eltérés a szüktürésü fajok (stenoök) esetében alakult ki. Külső-Somogyban ez meghaladja a $10 \%$-ot, Belső-Somogyban is $7 \%$. Ezzel szemben a Zselicben csak 2,7-, a Mecsekben pedig 5,2\%. Ez föleg a homokkedvelő fajok jelenléte vagy hiánya miatt van így. A legszélesebb türéshatárú (hypereuryök) fajok részesedése 10-14 százalék között változik, a legmagasabb a Zselicben. A hüvösebb biotópokat kedvelő (hylophil) fajok aránya nem a Mecsekben, hanem Külső- és Belső-Somogyban a legmagasabb, majdnem $10 \%$ (3. táblázat).

Az Elampini tribus fajait föleg gyeptársulások szegélyén, földpadkákon, növényzetmentes területeken gyüjtöttük. Az Omalus s.l. fajokat zömmel fák és cserjék lombozatán találtuk meg. A Chrysura fajok többsége a csigaház lakó Osmia (Megachilidae) fajok fészekparazitája. Gyüjtésük az arboreális szegélytársulásokban volt eredményes. A Chrysis fajok túlnyomó többsége löszpartokon és az ezeket helyettesítő régi épületek vályogfalain, vakolatlan téglafalazatain repül. Itt fészkelnek a gazdaállataik. A homokkedvelő fajok közül az alábbiak kerültek elő Dél-Dunántúlon: Chrysis bicolor, Ch. calimorpha, Ch. illigeri, Hedychidium femoratum, H. zelleri, Holopyga minuma, Parnopes grandior, Spinolia unicolor.

Vizsgáltuk a négy táj faunájának hasonlóságát is (4. táblázat). A legnagyobb hasonlóság a Mecsek és a Zselic esetében alakult ki (Jaccard index 0,73). A Zselic határos a Mecseket északról övező Baranyai-hegyháttal és a hegység nyugati részével, így a fajok élőhelyi feltételei a határzónában nagy hasonlóságot mutatnak. Ettől az értéktől alig tér el Külső- és Belső-Somogy esetében a 0,72-es index. Lehetséges magyarázat az lehet, hogy KülsőSomogy északi részén több, kisebb-nagyobb területű völgyválli homoklepel található. Ezek közül a legjelentősebb Kereki-Köröshegy és Látrány-Somogytúr határában található. Belső-Somogy pedig kiterjedt homokvidék. A homokkedvelő fajok tehát mindkét területen jelen vannak. A legkisebb hasonlóság (Jaccard index 0,65) Belső-Somogy és a Mecsek között mutatkozott. A két táj élőhelyi jellemzői markánsan különböznek.

Dél-Dunántúlon sok ritka faj került elö. Ezek közül külön említést érdemelnek azok, melyek magyarországi lelöhelyeinek száma nem több tíz-tizenkettőnél: Elampus bidens, Hedychridium chloropygum, H. elegantulum, H. zelleri, Pseudomalus triangulifer (Elampini), Chrysis brevitarsis, Ch. chrysoprasina, Ch. gribodoi spilota, Ch. grohmanni krkiana, Ch. phryne, Ch. placida, Ch. pulcherrima, Ch. schencki, Chrysura hirsuta, Pseudospinolia uniformis, Spinolia unicolor (Chrysidini). Hazánk faunájára új faj a $C h$. brevitarsis, Chrysis grohmanni krkiana, Chrysis taczanovskii. A Chrysis ignita fajcsoport revíziója során előkerült fajok, melyek a Magyarország Állatvilága XIII/2. füzetében nem szerepelnek: Chrysis clarinicollis, Ch. leptomandibularis, Ch. schencki, Ch. solida.

Az következő fajok hazai lelőhelyeinek jelentős hányada - gyüjtéseink eredményeképpen - Dél-Dunántúlon van: Hedychridium elegantulum, H. monochroum, H. valesiense, Chrysidea disclusa, Chrysis distincta, Ch. germari, Ch. gracillima, Ch. graelsii, Ch. grohmanni, Ch. leachii, Ch. leptomandibularis, Ch. ragusae, Ch. taczanovskii, Chrysura trimaculata, Pseudospinolia uniformis. 
A Magyarország Állatvilága Chrysidoidea füzetében nagyon kevés adat található a fémdarazsak táplálkozásáról. A szerző a gyüjtések során feljegyezte a fajok által látogatott növényeket. Ezeket az 5. táblázatban foglalta össze: 18 növénycsalád 36 nemének 63 fajáról kerültek elő fémdarazsak. A fémdarazsak rövid szájszervűek, leggyakrabban az ernyősök virágait keresik fel, mintegy húsz növényfajukról gyüjtöttünk, ezek közül kiemelkedik az Angelica sylvestris és a Pastinaca sativa. Tizenegy fészkesvirágú tápnövényt figyeltünk meg, a legkedveltebbnek a Matricaria inodora és az Achillea millefolium bizonyult. A Labiatae családban a Marrubium peregrinum és a Thymus fajok látogatottsága volt a legjelentősebb. Állataink nektárforrásai között jelentősnek bizonyultak az Euphorbia fajok is. A növények között sok a zavartürő faj, és két özönnövény is van: Stenactis annua, Solidago gigantea. A haszon- és dísznövények is jelentős szerepet játszanak a táplálékforrások biztosításában, köztük a Phoeniculum vulgare emelhető ki. A levéltetü mézharmat sok esetben helyettesítette a virágnektárt. A tetűvel fertőzött kislevelü hársak és őszibarackok lombozatát túlnyomóan a Chrysis- és az Omalus s.l. fajok látogatták.

\section{A ritkább fajok jegyzéke}

\section{Rövidítések}

MTM = Magyar Természettudományi Múzeum, RRM = Rippl-Rónai Múzeum

\section{Chrysidinae: Elampini}

Cleptes scutellaris Mocsáry, 1889 - Melegkedvelö nyugat-palearktikus tolvajdarázs. Magyarországon ritka, kilenc lelőhelyének egyike Simontornya.

Elampus bidens (Förster, 1853) - Palearktikus, széles türéshatárú fémdarázs faj. DélDunántúlon Mernyén, Barcson és Zselickisfaludon gyüjtöttük (coll. RRM). A Conium maculatum és a Pastinaca sativa virágait látogatta.

Elampus pyrosomus (Förster, 1853) - Közép-Európából ismert melegkedvelö faj. DélDunántúlon csak Kisvaszaron gyüjtötték (coll. MTM).

Elampus soror (Mocsáry, 1889) - Palearktikus elterjedési jellegü melegkedvelö tüskehátú-fémdarázs. Hazánkban elég ritka, a Dunántúl és az Alföld néhány pontján került elő. Dél-Dunántúlon Barcson, Pécsen és Mernyén fogtuk (coll. RRM).

Hedychridium aheneum (Dahlbom, 1854) - Melegkedvelő mediterrán aprófémdarázs. Magyarországon mindössze az Alföld két pontján és Balatonszemesen fogták (MóczÁR, 1967).

Hedychridium chloropygum Buysson, 1888 - Magyarországon négy lelöhelye ismert (Muskovits et al. manuscript): Hajdúszoboszló, Örbottyán, Isaszeg, Balatonszemes (coll. MTM). A faj MóczÁr (1967) publikációjában a H. roseum színváltozataként szerepel.

Hedychridium elegantulum Buysson, 1887 - Rika stenoök eremophil ökofaunisztikai jellegű aprófémdarázs. Móczár L. csak Isaszeg lelőhelyét közölte (MóczÁr 1967). DélDunántúlon elöször 1971-ben Pécsen gyüjtöttük. A következő évtizedekben elökerült Pécsváradon, Külső-Somogyban (Kereki, Köröshegy, Somogyaszaló) (coll. RRM), Barcson (JózAn 1998), továbbá Fenyőfön (JózAn 1998). A Magyar Természettudományi Múzeum gyüjteményében Kaposvárról is van példánya (MusKoviTs et al. manuscript). Lelöhelyeinek túlnyomó többsége homoktalajon van. A Trifolium arvense virágán fogtuk.

Hedychridium flavipes (Evermann, 1857) - Melegkedvelö palearktikus faj. Magyarországon elég ritka. Mintegy két tucatnyi lelöhelye Újfehértótól a Budai- 
hegységen keresztül Cserszegtomajig található. Dél-Dunántúlon a külső-somogyi Gamás és Somogyaszaló határában gyüjtöttük egy-egy példányát (coll. RRM). Az Angelica sylvestris fajt látogatta.

Hedychridium mediochrum Linsenmaier, 1987 - Melegkedvelő mediterrán faunaelem. Nálunk a Bakonyban, a Velencei- és a Budai-hegység néhány pontján, a Szekszárdidombvidéken, a Kiskunság két lelőhelyén és Tiszakécskén került elő (Muskovits et al. manuscript). Dél-Dunántúlon Cserkúton, Gamás Döbrököz és Kaposvár határában gyüjtöttük egy-egy példányát (coll. RRM). A Falcaria vulgaris és a Pastinaca sativa virágán került elő.

Hedychridium valesiense Linsenmaier, 1959 - Melegkedvelő palearktikus aprófémdarázs. MóczÁr (1967) mindössze három lelőhelyét említi. Az elmúlt évtizedekben Muskovits Jözsef hét helyen gyüjtötte. A szerző Külső-Somogyban hat, BelsőSomogyban egy, a Zselicben öt és a Mecsekben két helyen találta meg. Gyüjtötte még a Bakony-vidék öt pontján, továbbá az Örségben, a Villányi-hegységben, Szekszárd környékén és a Mátrában. Szinte mindenütt csak egy-egy példányát hálóztuk. Az Aegopodium podagraria és a Sium erectum virágain fogtuk.

Hedychridium zelleri (Dahlbom, 1845) - Palearktikus területeken élő melegkedvelő faj. Hazánkban egy tucatnyi lelőhelye Bátorligettől Belső-Somogyon át Mosonmagyaróvárig található (MusKoviTs et al. manuscript). Dél-Dunántúlon Somogyszobon (Baláta környéke) és Fonyódon gyüjtöttük. Homokkedvelő fajnak tünik.

Hedychrum longicolle Abeille, 1877 - Melegkedvelő palearktikus szépszínü-fémdarázs. Tizenöt magyarországi lelőhelyének egyike Kaposvár (coll. MTM). Dél-Dunántúlon csak ez a lelöhelye ismert.

Holopyga jurinei Chevrier, 1862 - Palearktikus területeken élő melegkedvelő épszélüfémdarázs faj. Két tucatnyi magyarországi lelőhelyéből csak három található DélDunántúlon (Nagybajom, Pécs, Simontornya). A Rippl-Rónai Múzeum gyüjteményében csak a Pécsről származó példány található.

Holopyga minuma Linsenmaier, 1959 - A palearktikus területeken élő, meleg-száraz élőhelyekhez ragaszkodó faj. A Kiskunságon számos helyen került elő, de DélDunántúlon ritkának bizonyult. Csak a Barcsi borókásban (Darány) és Kőkúton (BelsőSomogy) gyüjtöttük. Kifejezetten homokkedvelő állat. A Daucus carota, Gypsophila paniculata és a Seseli varium virágain találtuk meg.

Omalus biaccinctus (Buysson, 1893) - Melegkedvelő palearktikus aprófémdarázs. Régebben csak a Mecsekből, a Budai-hegységből és a Kőszegi-hegységből említik előfordulását (MóczÁr 1967). A hazai fémdarázs fauna revíziója során tizenöt újabb lelőhelye vált ismertté (MusKovits et al. manuscript). Dél-Dunántúlon gyüjtöttük KülsőSomogyban (Balatonboglár, Gamás és Siófok környéke) és Belső-Somogyban (Libickozma). A Rippl-Rónai Múzeum gyüjteményében egy-egy példány található Balatonfüredről (JózAN 2017) és Vindornyalakról.

Pseudomalus triangulifer (Abeille, 1877) - Elterjedése és környezeti igényei az előző fajjal egyeznek meg. Egy tucatnyi hazai lelőhelye közül Dél-Dunántúlon csak Szekszárdon (coll. MTM) és Kerekin (coll. RRM) gyüjtötték.

Pseudomalus violaceus (Scopoli, 1763) - Melegkedvelő palearktikus törpefémdarázs. Magyarországon mintegy két tucatnyi lelöhelyét ismerjük Füzérradványtól Köszegig. (MusKovits et al. manuscript). Dél-Dunántúlon a Baranyai-hegyháton (Tékes), a Barcsi borókás TK-ban (JózAN 2015) a Látrányi Puszta TVT-n (JóZAN 2003) és Kisbárapáti határában gyüjtöttük. Megtaláltuk a Bakonyban is (JózAN 1998). A Seseli varium virágán gyüjtöttük. 


\section{Chrysidinae: Chrysidini}

Chrysis angustifrons Abeille, 1878 - Pontomediterrán melegkedvelő aranyruhásfémdarázs. Másfél tucatnyi hazai lelőhelyének többsége Budapest környékén és a Dunántúlon található. A Mecsekben két lelőhelyen került elő: Pécs: Kertváros, Zsebedomb (JóZAN 2006). Külső-Somogyban egy lelöhelyét ismerjük Látrány környékéről (JózAN 2003). A múlt század közepén Vörsön is megtalálták (coll. MTM).

Chrysis brevitarsis Thomson, 1870 - Nyugat palearktikus melegkedvelö fémdarázs. MóczÁr (1967) magyarországi előfordulását nem említi. Muskovits J. Örkénynél és Pilisborosjenőn gyüjtötte. A szerző a Boronka-melléki TK faunisztikai vizsgálata során egy példányát megtalálta Nagybajom környékén (Nagybajom: Nagy-homok 1990. VIII. 10. 1 nőstény). Magyarország faunájára új.

Chrysis calimorpha Mocsáry, 1882 - Elterjedése és környezeti igényei az előző fajhoz hasonlóak. Muskovits J. mintegy harminc magyarországi lelőhelyről származó példányait determinálta. Dél-Dunántúlon csak Darány környékéről és Balatonszemesről (coll. RRM), valamint Vörsröl (MTM) került elö.

Chrysis chrysoprasina Förster, 1853 - Meleghez és szárazsághoz erősen ragaszkodó pontomediterrán faj. Muskovits a Budai-hegység két pontján gyűjtötte (Pilisborosjenő, Törökbálint) (MusKoviTs et al. manuscript). A szerző egy-egy példányát Fülöpháza környékén, Kerekiben (Külső-Somogy) és Sukorón találta meg. Magyarország faunájára új. Az Eryngium campestre virágát látogatta.

Chrysis chrysostigma MocsáRY, 1889 (ramburi sensu Móczár 1967) - Melegkedvelő mediterrán fémdarázs faj. Régebbről csak simontornyai előfordulása ismert (MóczÁR 1967). Az utóbbi évtizedekben tizennégy helyen került elö Magyarországon. Ezek többsége a hegységeink meleg mezoklímájú hegylábi övezetében található, néhány pedig dombvidéken van. Mindössze egy példányát fogtuk alacsony fekvésü területen a belsősomogyi Baláta környékén. A Mecsekben három helyen gyüjtöttük (Orfü, Pécs: Szabolcsfalu, Zsebe-domb), a Zselicben Cserénfán és Külső-Somogyban Kerekinél került elö. A bakonyi lelöhelyeit már közöltük (JózAN 1998).

Chrysis clarinicollis Linsenmaier, 1951 - Valószínűleg melegkedvelő nyugat-palearktikus faunaelem. Muskovits J. tizenegy lelőhelyét tartja számon. Ezek túlnyomó többsége Budapest környékén van. A szerző Külső-Somogyban (Balatonföldvár, Kereki, Mernye), Belső-Somogyban (Bélavár, Mike) és a Zselicben (Simonfa) gyűjtötte. Megtalálta a Balaton-felvidéken is (Tihany, Balatonfüzfö). Az ignita fajcsoport revíziója során került a magyarországi fémdarázs fajok közé.

Chrysis coeruleiventris Abeille, 1878 - Szüktürésü melegkedvelö mediterrán fémdarázs. A múlt évszázad közepén csak három hazai lelőhelye volt ismert (MóczÁR 1967). Ezt követően hét újabb helyen került elö, többek között Balatonszemesen (Muskovits et al. manuscript). A szerző megtalálta Balatonhenyén (JóZAN 1994).

Chrysis comparata Lepeletier, 1806 - Elterjedése és környezeti igényei az előzőfajhoz hasonlóak. Húsznál valamivel több lelőhelyét Békés megyétől a Vend-vidékig találjuk. Dél-Dunántúlon Szekszárdon és Zamárdiban gyüjtötték (MusKoviTs et al. manuscript). A szerző Felsőszölnökön fogta (JózAN 2002).

Chrysis consanguinea prominea Linsenmaier, 1959 - Nyugat-palearktikus területeken elterjedt faj. A viridula fajcsoportba tartozik. Elkülönítése bizonytalan. Dél-Dunántúlon csak a Zselicben (Gálosfa) és Külső-Somogyban (Balatonszemes) találtuk meg. Elökerült Simontornyán (coll. Muskovits) Pécsen és Szekszárdon (coll. MTM) is (MusKovits et al. manuscript).

Chrysis frivaldszkyi Mocsáry, 1882 - Melegkedvelő kelet-mediterrán fémdarázs. Hazánkban sokfelé előkerült, de Dél-Dunántúlon ritkább. Külső-Somogyban Balatonszéplakon, Siófokon és Zamárdiban gyüjtötték. Megtalálták a Szekszárdidombságon és Vörsnél is. 
Chrysis gribodoi spilota Linsenmaier, 1951 - Közép-Európában ismert faj. A Chrysis bicolor közeli rokona. Magyarországon ritka, csak Dunakeszin és Törökbálinton (coll. Muskovits) és Vörsön (coll. MTM) került elö.

Chrysis grohmanni krkiana Linsenmaier, 1959 - A gyakori grohmanni alfaja. Elkülönítése a törzsfajtól nem könnyü. Muskovits J. Simontornyán gyüjtötte. Hazánk faunájára új (MusKoviTs et al. manuscript).

Chrysis interjecta Buysson, 1895 - Melegkedvelő holomediterrán faj. Csak három magyarországi lelöhelyét ismerjük (MóczÁR 1967). Muskovits J. tíz Budapest környéki helyen és Simontornyán gyüjtötte. A szerző Belső-Somogyban (Bélavár: Kerék-hegy, Sul; Homokszentgörgy) és a Zselicben (Bőszénfa) találta meg. A Balaton-felvidéken (Balatonszőlős, Csopak) a Tapolcai-medencében (Káptalantóti) és Balatonkenesén is gyüjtöttük.

Chrysis leptomandibularis Niehuis, 2000 - Nyugat-palearktikumban ismert fémdarázs faj. Muskovits J. négy lelőhelyét ismertette. Lelőhelyeinek többsége Dél-Dunántúlon van: Külső-Somogy (Bonnyapuszta, Mernye, Osztopán), Belső-Somogy (Barcs, Csököly, Böhönye, Marcali: Gyótapuszta, Mike, Nagybajom, Vízvár), Zselic (Kaposszerdahely). ARippl-Rónai Múzeum gyüjteményében van példánya Nadapról, Sáskáról és Tiszasülyről is. Az ignita fajcsoport revíziója során került a magyarországi fémdarázs fajok közé.

Chrysis longula Abeille, 1879 - Nyugat-palearktikus, inkább hüvösebb mikroklímájú élőhelyeket kedvelő faj. Másfél tucatnyi hazai lelőhelyét Egertől Sopronig találjuk meg (MusKovits et al. manuscript). Dél-Dunántúlon csak Balatonszemes (coll. MTM), Alsótapazd (Kőkút) és Ecseny lelőhelyekről (coll. RRM) ismerjük.

Chrysis marginata Mocsáry 1889 - Melegkedvelő pontomediterrán fémdarázs. Magyarországon sokfelé elökerült, de nem közönséges faj. Muskovits ötvennél több lelőhelyét sorolta fel (MusKoviTs et al. manuscript). Ebből majdnem harminc gyüjtőhely bizonyító példányai a Rippl-Rónai Múzeum Chrysididae anyagában találhatók. Lelöhelyei Külső-Somogyban Kaposvár, Kereki: halastónál, Kereki: belterület, Mernye, Siófok: Töreki, Tab; Belső-Somogyban Somogyszob: Kaszó; a Zselicben Hedrehely, Ibafa, Kaposgyarmat, Kaposhomok, Zselickislak, Zsibót; a Mecsekben Cserkút, Komló Sikonda, Pécs: Tettye. A vizsgált területen előkerült még Drávafokon, Szekszárdon és Vokányban. Viráglátogatása: Daucus carota, Heracleum sphondylium, Levisticum officinale, Pastinaca sativa, Phoeniculum vulgare, Euphorbia cyparissias, Euphorbia marginata.

Chrysis mediadentata Linsenmaier, 1959 - Európából ismert fémdarázs. Muskovits J. négy dél-dunántúli lelőhelyét sorolta fel (Muskovits et al. manuscript). A Rippl-Rónai Múzeum gyüjteményében található példányok Külső-Somogyból (Felsőmocsolád: Kisbabapuszta, Polány), Belső-Somogyból (Inke), a Zselicből (Simonfa) és a Mecsekből (Kovácsszénája) származnak.

Chrysis millenaris Mocsáry, 1897 - Melegkedvelő pontomediterrán faj. Hazánkban húsz helyen került elő. Dél-Dunántúlon Belső-Somogyban két (Kőkút, Segesd) KülsőSomogyban egy (Balatonboglár) lelőhelyen fogtuk. A Bakonyban Pécselyen (JózAN 1998), majd később Csopakon és Szentbékkállán (coll. RRM) gyüjtöttük. Megtaláltuk a Velencei-hegységben is Pákozd és Sukoró határában (coll. RRM).

Chrysis phryne Abeille, 1878 - Ritka mediterrán fémdarázs. Magyarországon mindössze tíz lelőhelyét ismerjük. Dél-Dunántúlon két mecseki lelőhelyén kívül (Pécs: Bárány-tető, Tettye) (JózAN 1998) előkerült a Villányi-hegységben Nagyharsánynál is (coll. MTM). A Bakonyban Balatonhenyén gyüjtöttük (JózAN 1998), majd később Öskün is. A Daucus carota virágán találtuk meg. 
Chrysis placida Mocsáry, 1879 - Közép-Európából ismert melegkedvelő faj. Nálunk mintegy tucatnyi helyen gyüjtötték. A vizsgált területen csupán Simontornyán került elö (coll. Muskovits, coll. MTM).

Chrysis pseudobrevitarsis Linsenmaier, 1951 - Nyugat-palearktikus fémdarázs. Muskovits J. tizenöt magyarországi lelöhelyét sorolta fel, ebböl kilenc a Bakony-vidéken van (Muskovits et al. manuscript). Dél-Dunántúlon további tíz helyen sikerült megtalálni: Külső-Somogy (Bedegkér, Kaposvár: Toponár), Belső-Somogy (Somogyszob: Kaszó, Somogyudvarhely, Somogyzsitfa, Vízvár), Zselic (Bakóca, Somogyhatvan). Mecsek (Komló: Sikonda), Baranyai-hegyhát (Husztót).

Chrysis pulcherrima Lepeletier, 1806 - Európából ismert faj, melyet Spanyolországtól Romániáig mutattak ki. A viridula fajcsoporthoz tartozik. Hazánkban hat lelöhelyröl ismerjük (MusKoviTs et al. manuscript), ebböl kettő van Dél-Dunántúlon: Simontornya és Szekszárd.

Chrysis schencki Linsenmaier, 1968 - Pontomediterrán faunaelem. Muskovits J. hat lelőhelyét sorolta fel a Cserháttól a Kerka-vidékig. Dél-Dunántúlon két belső-somogyi (Babócsa, Kisasszond) és egy külső-somogyi (Szentgáloskér) gyüjtőhelye ismert (coll. RRM). Gyüjtöttük még a Keleti-Bakonyban (Öskü) is. Az ignita fajcsoport revíziója során került a magyarországi fémdarázs fajok közé.

Chrysis sexdentata Christ, 1791 - Melegkedvelő pontomediterrán fémdarázs faj. Magyarországon tizenháromlelöhelyébőlhárom található Dél-Dunántúlon:Balatonboglár, Iregszemcse és Szekszárd (MusKoviTs et al. manuscript).

Chrysis solida Haupt, 1956 - Nyugat-palearktikus faj. Muskovits J. hat lelöhelyét sorolta fel Gyulától Budapesten át Fenyőföig. Dél-Dunántúlon tizennégy helyen gyüjtöttük. Külső-Somogyban Alsóbogát, Balatonszemes, Gamás, Látrány, Mernye, Mernyeszentmiklós, Magyaregres, Toponár (Kaposvár), Ráksi: Belső-Somogyban Barcsi borókás (Darány), Kiskorpád, Libickozma, Pat: a Zselicben Szentbalázs és a Mecsekben Pécs: Tettye. Az ignita fajcsoport revíziója során került a magyarországi fémdarázs fajok közé.

Chrysis soror Dahlbom, 1854 - Közép-Európából ismert fémdarázs faj. A comparata - scutellaris fajcsoportba tartozik. Magyarországon ritka, tizennégy lelöhelyének egyike Fonyód (Muskovits et al. manuscript).

Chrysis splendidula Rossi, 1790 - Melegkedvelő pontomediterrán fémdarázs. Magyarországon sokfelé előkerült Sárospataktól és Szegedtől Dél-Dunántúlig és a Bakonyig. Dél-Dunántúlon csak hét lelöhelye ismert: Külső-Somogyban (Balatonlelle, Látrány, Nagyberény, Zamárdi), a Zselicben, és a Tolnai-hegyháton (Hőgyész, Simontornya). Viráglátogatása: Pastinaca sativa, Spiraea sp.

Chrysis subsinuata Marquet, 1879 - Elterjedési jellege és környezeti igényei az előző fajhoz hasonlóak. Muskovits J. a Kiskunságról, Budapest környékéről és a Bakonyból determinálta a példányait. Dél-Dunántúlon eléggé ritka, Külső-Somogyban Gamáson, Somogyaszalóban és Somogybabodon, Belső-Somogyban Szuloknál, a Zselicben Cserénfán és a Mecsekben Abaligeten és Hosszúhetényben gyüjtöttük (coll. RRM).

Chrysis taczanovskii Radoszkowski, 1876 - Melegkedvelő mediterrán faj. A Magyar Természettudományi Múzeum gyüjteményében e fajnak nincsenek példányai. Hazánkban csak az utóbbi évtizedekben került elő. Dél-Dunántúlon egyre több lelőhelyen találtuk meg. Ezek többsége a Zselicben van: Bakóca, Baranyaszentgyörgy, Csebény, Cserénfa, Horváthertelend, Kaposgyarmat, Kaposkeresztúr, Kisbeszterce, Mindszentgodisa belterület, Mindszentgodisa Gyümölcsény, Palé, Patca, Somogyhárságy, Somogyhatvan, Szágy, Szilvásszentmárton, Vásárosbéc. További lelöhelyei Külső-Somogyban Somogyaszaló: Antalmajor, Somogyaszaló: községi szőlö, Somogygeszti, Belső-Somogyban Mike és Kőkút, a Mecsekben Abaliget és Kovácsszénája, a Dráva-síkon Drávasztára és Vejti, a 
Baranyai hegyháton Varga. Gyurkovics Henrik Szegeden gyüjtötte (szóbeli közlés). Első példányát Vejtiben gyüjtöttük a 1996-ban a Duna-Dráva NP kutatása során. Az utóbbi évtizedben végzett gyüjtéseink alapján a faj terjeszkedését feltételezhetjük. Hazánk faunájára új. Tápnövényei: Heracleum sphondylium, Levisticum officinale, Phoeniculum vulgare.

Chrysis viennensis Linsenmaier, 1959 - A cinglicornis-tól nehezen elkülöníthető faj. Muskovits J. tizenhárom helyen gyüjtötte, ezek egyike Simontornya.

Chrysura austriaca (Fabricius, 1804) - Hüvös klímájú élőhelyeket kedvelő palearktikus faj. Magyarországon ismert lelőhelyeinek száma nem éri el a húszat (MóczÁr 1967, MusKovits etal.manuscript). Dél-Dunántúlon csakAlsóbogáton és Balatonbogláron (Külső-Somogy) továbbá Mecseknádasdon (Mecsek) ismerjük előfordulását.

Chrysura hirsuta (Gerstaecker, 1869) - Nagyon ritka nyugat-palearktikus hylophil faj. Régebben csak Keszthelyről ismertük előfordulását (Móczár 1967). Egy újabb lelőhelye vált ismertté Kaposváron (coll. MTM).

Chrysura radians (Harris, 1776) - Hüvösebb mikrokímájú élőhelyeket kedvelő palearktikus faj. Magyarországon majdnem negyven helyen találták meg (MusKoviTs et al. manuscript). Dél-Dunántúlon csak négy lelőhelye ismert: Balatonboglár és Vörs (coll. MTM), továbbá Abaliget és Törökkoppány (coll. RRM).

Chrysura simplex (Dahlbom, 1854) - Főleg hegyvidékeken élő mediterrán elterjedési jellegü fémdarázs. Móczár (1967) csak budapesti lelöhelyét említi. Muskovits J. a revízió során az MTM gyüjteményében további öt lelőhelyről talált példányokat. Köztük kettő a Dél-Dunántúlon van: Szekszárd és Vörs.

Chrysura trimaculata (Förster, 1853) - Pontomediterrán faj. Tavasszal rajzik, március végén már gyüjtöttük. A múlt évszázad közepéig csak négy hazai helyről közölték (MóczÁr 1967). Azóta harmincötre gyarapodott a lelőhelyeinek száma, ebből tizenhét található Dél-Dunántúlon. Külső-Somogy: Gamás Jazvina, Látrány, Polány, Magyaregres Deseda, Somogydöröcske, Somogyaszaló Desda; Belső-Somogy: Darány Barcsi borókás TK, Mike, Somogyfajsz; Zselic: Almamellék Sasrét, Bárdudvarnok, Ibafa Gyürüfü, Kaposmérö, Somogyhárságy, Szentbalázs, Töröcske (Kaposvár); Mecsek: Hosszúhetény Püspökszentlászló, Pécs Jakabhegy; Dráva-völgy: Örtilos.

Euchroeus purpuratus (Fabricius, 1787) - Meleghez és szárazsághoz erősen ragaszkodó pontomediterrán fémdarázs. Főleg az Alföldön és a meleg mezoklímájú hegylábi övezetekben gyüjtötték. Dél-Dunántúlon csak a Balaton partja mentén (Balatonboglár, Balatonszemes, Balatonőszöd, Zamárdi), a Kisbalatonnál (Vörs) és Szekszárdon ismerjük előfordulását (coll. MTM). A Rippl-Rónai Múzeum gyüjteményében csak egy Balatonszemesen gyüjtött példány található.

Pseudospinolia uniformis (Dahlbom, 1854) - Melegkedvelő pontomediterrán faj. A faunafüzetben (MóczÁr 1967) hazai előfordulását nem említik. Az utóbbi évtizedekben Muskovits Cserkúton (Mecsek) és Gyulán gyüjtötte. A szerző elsőként Óbányán találta meg (JózAN 2006). Az elmúlt években előkerült a Zselicben (Almamellék: Sasrét) és Magyarszék (Mecsek) határában (coll. RRM). Kovács-Hostyánszki Anikó a Hevesi puszták TVK kutatása során e faj több példányát fogta csapdával Besenyőtelek, Mezőtárkány és Poroszló határában.

Spinolia dallatorreana Mocsáry, 18996 - Szüktürésű melegkedvelő pontomediterrán fémdarázs. Magyarországon tizenhárom lelőhelye ismert. Dél-Dunántúlon csak régi előfordulásai vannak: Simontornya, Siófok és Szekszárd (coll. MTM).

Spinolia unicolor (Dahlbom, 1831) - Palerktikus fémdarázs, ökológiai igényei az előző fajjal egyeznek meg. Homokterületeken került elő. Tíz lelőhelye a Kiskunságon, Bakonyszentkirályon, Keszthelyen és Gyenesdiáson van. Dél-Dunántúlon Pécs Zsebedomb, Somogytúr (Külső-Somogy) és Nagybajom (Belső-Somogy). A homokterületeken kívül gyüjtöttük dolomit- és homokkő konglomerátum málladékon is. 


\section{Parnopinae}

Parnopes grandior (Pallas, 1771) - Meleghez és szárazsághoz erősen ragaszkodó, a palearktikumban elterjedt fémdarázs. A Bembix (Crabronidae) fajok fészekparazitája, szinte kizárólag homokterületeinken került elö. A pécsi Zsebe-dombon homokkőkonglomerátum málladékán is gyüjtöttük. Magyarországon eddig negyvenöt lelöhelye ismert (MusKoviTs et al. manuscript). Dél-Dunántúlon ebből tizenhárom található.

Külső-Somogyban Látrány, Somogytúr és Zamárdi; Belső-Somogyban Barcs, Bélavár, Darány, Kökút, Nagybajom, Rinyaszentkirály, Somogyszob, Tótújfalu; a Mecsekben Hird, Pécs Szabolcsfalu és Zsebe-domb. Látogatott növények: Centurea micranthos, Euphorbia seguierana, Jasione montana, Knautia arvensis, Scabiosa ochroleuca, Thymus sp.,Trifolium arvense. 


\section{1. táblázat: A fajok jegyzéke és lelőhelyeinek száma tájanként}

\begin{tabular}{|c|c|c|c|c|c|c|}
\hline alcsalád és nemzetség & faj & 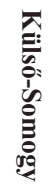 & 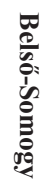 & 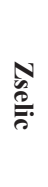 & $\begin{array}{l}3 \\
\frac{2}{2} \\
\frac{0}{2} \\
\frac{0}{2}\end{array}$ & 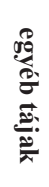 \\
\hline Celptinae & Cleptes nitidulus (Fabricius, 1793) & 2 & 2 & & & 2 \\
\hline Celptinae & Cleptes pallipes Lepeletier 1806 & 4 & 2 & & & 3 \\
\hline Celptinae & Cleptes scutellaris Mocsary, 1889 & & & & & 1 \\
\hline Celptinae & Cleptes semiauratus (Linnaeus, 1761) & 2 & 1 & & & 1 \\
\hline Celptinae & Cleptes splendidus (Fabricius,1793) & 1 & 2 & & 1 & 1 \\
\hline Chrysidinae: Elampini & Elampus constrictus (Förster, 1853) & 2 & 1 & & 1 & 1 \\
\hline Chrysidinae: Elampini & Elampus bidens (Förster, 1853) & 2 & 2 & 1 & & \\
\hline Chrysidinae: Elampini & Elampus panzeri (Fabricius, 1804) & 1 & 4 & 1 & & 2 \\
\hline Chrysidinae: Elampini & Elampus pyrosomus (Förster, 1853) & & & & & 1 \\
\hline Chrysidinae: Elampini & Elampus sanzii Gogorza, 1887 & 1 & & & 1 & 3 \\
\hline Chrysidinae: Elampini & Elampus soror (Mocsáry, 1889) & 1 & 1 & & 1 & 1 \\
\hline Chrysidinae: Elampini & Elampus spina (Lepeletier, 1806) & & & & & 2 \\
\hline Chrysidinae: Elampini & Hedychridium aheneum (Dahlbom, 1854) & 1 & & & & \\
\hline Chrysidinae: Elampini & Hedychridium ardens (Coquebert, 1801) & 23 & 4 & 5 & 3 & 5 \\
\hline Chrysidinae: Elampini & Hedychridium caputaureum Trautmann, 1919 & 11 & 4 & 3 & 3 & 4 \\
\hline Chrysidinae: Elampini & Hedychridium chloropygum Buysson, 1888 & & & & & 1 \\
\hline Chrysidinae: Elampini & Hedychridium coriaceum (Dahlbom, 1854) & 44 & 16 & 14 & 11 & 12 \\
\hline Chrysidinae: Elampini & Hedychridium elegantulum Buysson, 1887 & 3 & 1 & 1 & 2 & \\
\hline Chrysidinae: Elampini & Hedychridium femoratum (Dahlbom, 1854) & 2 & 1 & & 1 & 1 \\
\hline Chrysidinae: Elampini & Hedychridium flavipes (Eversmann, 1857) & 2 & & & & 1 \\
\hline Chrysidinae: Elampini & Hedychridium jucundum (Mocsáry, 1889) & 20 & 19 & 6 & 2 & 7 \\
\hline Chrysidinae: Elampini & Hedychridium krajniki Balthasar, 1946 & 2 & & 2 & 1 & 1 \\
\hline Chrysidinae: Elampini & Hedychridium lampadum Linsenmaier, 1959 & 6 & & & & 3 \\
\hline Chrysidinae: Elampini & Hedychridium mediochrum Linsenm., 1987 & 2 & & & 1 & 3 \\
\hline Chrysidinae: Elampini & Hedychridium monochroum Buysson, 1888 & 9 & 5 & 8 & 3 & 10 \\
\hline Chrysidinae: Elampini & Hedychridium roseum (Rossi, 1790) & 25 & 9 & 21 & 3 & 14 \\
\hline Chrysidinae: Elampini & Hedychridium valesiense Linsenmaier, 1959 & 11 & 2 & 9 & 3 & 6 \\
\hline Chrysidinae: Elampini & Hedychridium zelleri (Dahlbom, 1845) & 1 & 2 & & & \\
\hline Chrysidinae: Elampini & Hedychrum gerstaeckeri Chevrier, 1869 & 41 & 17 & 17 & 9 & 14 \\
\hline Chrysidinae: Elampini & Hedychrum longicolle Abeille, 1877 & & & 1 & & \\
\hline Chrysidinae: Elampini & Hedychrum niemelai Linsenmaier, 1959 & 24 & 4 & 12 & 6 & 17 \\
\hline Chrysidinae: Elampini & Hedychrum nobile (Scopoli, 1763) & 51 & 21 & 15 & 5 & 20 \\
\hline Chrysidinae: Elampini & Hedychrum rutilans Dahlbom, 1854 & 40 & 16 & 5 & 3 & 9 \\
\hline
\end{tabular}




\section{1. táblázat: A fajok jegyzéke és lelőhelyeinek száma tájanként}

\begin{tabular}{|c|c|c|c|c|c|c|}
\hline alcsalád és nemzetség & faj & 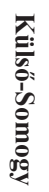 & 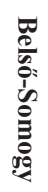 & $\begin{array}{l}\mathbf{N} \\
\stackrel{\infty}{\sigma}\end{array}$ & $\begin{array}{l}\frac{3}{8} \\
\frac{0}{2} \\
\frac{8}{2}\end{array}$ & 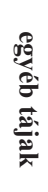 \\
\hline Chrysidinae: Elampini & Holopyga chrysonota (Förster, 1853) & 8 & 7 & 3 & 1 & 2 \\
\hline Chrysidinae: Elampini & Holopyga fervida (Fabricius, 1781) & 8 & & 1 & 5 & 2 \\
\hline Chrysidinae: Elampini & Holopyga generosa (Förster, 1853) & 25 & 9 & 5 & 9 & 14 \\
\hline Chrysidinae: Elampini & Holopyga ignicollis Dahlbom, 1854 & 20 & 3 & 2 & 2 & 3 \\
\hline Chrysidinae: Elampini & Holopyga inflammata (Förster, 1853) & 6 & & & 2 & 1 \\
\hline Chrysidinae: Elampini & Holopyga jurinei Chevrier, 1862 & & 1 & & 1 & 1 \\
\hline Chrysidinae: Elampini & Holopyga minuma Linsenmaier, 1959 & & 2 & & & \\
\hline Chrysidinae: Elampini & Omalus aeneus (Fabricius, 1787) & 14 & 7 & 1 & 3 & 6 \\
\hline Chrysidinae: Elampini & Omalus biaccinctus (Buysson, 1893) & 3 & 2 & & 2 & \\
\hline Chrysidinae: Elampini & Philoctetes bidentulus (Lepeletier, 1806) & 7 & 1 & 3 & 2 & 4 \\
\hline Chrysidinae: Elampini & Philoctetes truncatus (Dahlbom, 1831) & 7 & 1 & 4 & 3 & 3 \\
\hline Chrysidinae: Elampini & Pseudomalus auratus (Linnaeus, 1761) & 31 & 14 & 17 & 5 & 13 \\
\hline Chrysidinae: Elampini & Pseudomalus bogdanovi (Rad., 1877) & 3 & 2 & 1 & 2 & 3 \\
\hline Chrysidinae: Elampini & Pseudomalus pusillus (Fabricius, 1804) & 36 & 19 & 16 & 3 & 9 \\
\hline Chrysidinae: Elampini & Pseudomalus triangulifer (Abeille, 1877) & 1 & & & & 1 \\
\hline Chrysidinae: Elampini & Pseudomalus violaceus (Scopoli, 1763) & 2 & 1 & & & 1 \\
\hline Chrysidinae: Chrysidini & Chrysidea disclusa Linsenmaier, 1959 & 33 & 11 & 33 & 7 & 19 \\
\hline Chrysidinae: Chrysidini & Chrysis angustifrons Abeille, 1878 & 1 & & & 2 & 1 \\
\hline Chrysidinae: Chrysidini & Chrysis angustula Schenck, 1856 & 4 & 1 & 1 & & 3 \\
\hline Chrysidinae: Chrysidini & Chrysis bicolor Lepeletier, 1806 & 6 & 21 & & & 1 \\
\hline Chrysidinae: Chrysidini & Chrysis brevitarsis Thomson, 1870 & & 1 & & & \\
\hline Chrysidinae: Chrysidini & Chrysis calimorpha Mocsáry, 1882 & 1 & 1 & & & 1 \\
\hline Chrysidinae: Chrysidini & Chrysis chrysoprasina Förster, 1853 & 1 & & & & \\
\hline Chrysidinae: Chrysidini & Chrysis chrysostigma Mocsáry, 1889 & 1 & 1 & 1 & 3 & 1 \\
\hline Chrysidinae: Chrysidini & Chrysis clarinicollis Linsenmaier, 1951 & 3 & 2 & 1 & & \\
\hline Chrysidinae: Chrysidini & Chrysis cingulicornis Förster, 1853 & 12 & 1 & 7 & 1 & 9 \\
\hline Chrysidinae: Chrysidini & Chrysis coeruleiventris Abeille, 1878 & 1 & & & & \\
\hline Chrysidinae: Chrysidini & Chrysis comparata Lepeletier, 1806 & 1 & & & & 1 \\
\hline Chrysidinae: Chrysidini & Chrysis comta Förster, 1853 & 7 & 2 & 4 & & 4 \\
\hline Chrysidinae: Chrysidini & Chrysis consanguinea prominea Linsen.,1959 & 1 & & 1 & 1 & 2 \\
\hline Chrysidinae: Chrysidini & Chrysis distincta Mocsáry, 1887 & 6 & 5 & 27 & 4 & 17 \\
\hline Chrysidinae: Chrysidini & Chrysis fasciata Olivier, 1790 & 2 & 2 & 3 & 1 & 2 \\
\hline Chrysidinae: Chrysidini & Chrysis frivaldszkyi Mocsáry, 1882 & 3 & & & & 3 \\
\hline
\end{tabular}




\section{1. táblázat: A fajok jegyzéke és lelőhelyeinek száma tájanként}

\begin{tabular}{|c|c|c|c|c|c|c|}
\hline alcsalád és nemzetség & faj & 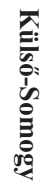 & 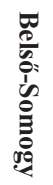 & 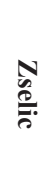 & $\begin{array}{l}3 \\
\frac{2}{2} \\
\frac{0}{2} \\
\frac{0}{2}\end{array}$ & 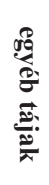 \\
\hline Chrysidinae: Chrysidini & Chrysis fulgida Linnaeus, 1761 & 9 & 2 & 2 & 3 & 1 \\
\hline Chrysidinae: Chrysidini & Chrysis germari Wesmael, 1839 & 18 & 5 & 8 & 7 & 5 \\
\hline Chrysidinae: Chrysidini & Chrysis gracillima Förster, 1853 & 25 & 12 & 23 & 6 & 7 \\
\hline Chrysidinae: Chrysidini & Chrysis graelsii Guérin, 1842 & 9 & 12 & 17 & 4 & 4 \\
\hline Chrysidinae: Chrysidini & Chrysis gribodoi spilota Linsenm. 1951 & & & & & 1 \\
\hline Chrysidinae: Chrysidini & Chrysis grohmanni Dahlbom, 1854 & 28 & 17 & 27 & 8 & 14 \\
\hline Chrysidinae: Chrysidini & Chrysis grohmanni krkiana Linsenm,,1959 & & & & & 1 \\
\hline Chrysidinae: Chrysidini & Chrysis ignita (Linnaeus, 1758) & 51 & 35 & 29 & 9 & 15 \\
\hline Chrysidinae: Chrysidini & Chrysis illigeri Wesmael, 1839 & 5 & 14 & 1 & 1 & 3 \\
\hline Chrysidinae: Chrysidini & Chrysis impressa Schenck, 1856 & 11 & 3 & 2 & 2 & 1 \\
\hline Chrysidinae: Chrysidini & Chrysis inequalis Dahlbom, 1845 & 16 & 12 & 6 & 1 & 6 \\
\hline Chrysidinae: Chrysidini & Chrysis indigotea Dufour \& Perris, 1840 & 4 & 11 & 3 & 1 & 2 \\
\hline Chrysidinae: Chrysidini & Chrysis insperata Chevrier, 1870 & 1 & 4 & & & 1 \\
\hline Chrysidinae: Chrysidini & Chrysis interjecta Buysson, 1895 & & 3 & 1 & & 1 \\
\hline Chrysidinae: Chrysidini & Chrysis iris Christ, 1791 & 2 & 1 & 10 & 3 & 1 \\
\hline Chrysidinae: Chrysidini & Chrysis lanceolata Linsenmaier, 1959 & 1 & 2 & 1 & & 2 \\
\hline Chrysidinae: Chrysidini & Chrysis leachii Shuckard, 1836 & 36 & 25 & 28 & 10 & 17 \\
\hline Chrysidinae: Chrysidini & Chrysis leptomandibularis Niehuis, 2000 & 3 & 7 & 1 & & \\
\hline Chrysidinae: Chrysidini & Chrysis longula Abeille, 1879 & 2 & 1 & & & \\
\hline Chrysidinae: Chrysidini & Chrysis marginata Mocsáry, 1889 & 6 & 1 & 6 & 3 & 3 \\
\hline Chrysidinae: Chrysidini & Chrysis mediadentata Linsenmaier, 1959 & 2 & 1 & 2 & 2 & 2 \\
\hline Chrysidinae: Chrysidini & Chhrysis mediata Linsenmaier, 1951 & 36 & 1 & 36 & 10 & 16 \\
\hline Chrysidinae: Chrysidini & Chrysis millenaris Mocsáry, 1897 & 1 & 2 & & & \\
\hline Chrysidinae: Chrysidini & Chrysis phryne Abeille, 1878 & & & & 2 & 1 \\
\hline Chrysidinae: Chrysidini & Chrysis placida Mocsáry, 1879 & & & & & 1 \\
\hline Chrysidinae: Chrysidini & Chrysis pseudobrevitarsis Linsenm.,1951 & 2 & 2 & 3 & 1 & 1 \\
\hline Chrysidinae: Chrysidini & Chrysis pulchella Spinola, 1808 & 5 & 2 & 1 & 2 & 2 \\
\hline Chrysidinae: Chrysidini & Chrysis pulcherrima Lepeletier, 1806 & & & & & 2 \\
\hline Chrysidinae: Chrysidini & Chrysis ragusae Destefani, 1888 & 21 & 18 & 39 & 11 & 14 \\
\hline Chrysidinae: Chrysidini & Chrysis rutilans Olivier, 1790 & 22 & 10 & 14 & 4 & 8 \\
\hline Chrysidinae: Chrysidini & Chrysis rutiliventris Abeille, 1879 & 3 & & 3 & 1 & 2 \\
\hline Chrysidinae: Chrysidini & Chrysis schencki Linsenmaier, 1968 & 1 & 2 & & & \\
\hline Chrysidinae: Chrysidini & Chrysis scutellaris Fabricius, 1794 & 14 & & 10 & 5 & 5 \\
\hline
\end{tabular}




\section{1. táblázat: A fajok jegyzéke és lelőhelyeinek száma tájanként}

\begin{tabular}{|c|c|c|c|c|c|c|}
\hline alcsalád és nemzetség & faj & 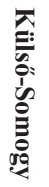 & 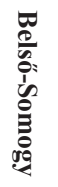 & 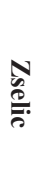 & $\begin{array}{l}3 \\
\frac{3}{2} \\
\frac{8}{2} \\
\frac{0}{2}\end{array}$ & 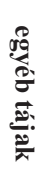 \\
\hline Chrysidinae: Chrysidini & Chrysis sexdentata Christ, 1791 & 2 & & & & 1 \\
\hline Chrysidinae: Chrysidini & Chrysis solida Haupt, 1956 & 8 & 4 & 1 & 1 & \\
\hline Chrysidinae: Chrysidini & Chrysis soror Dahlbom, 1854 & 1 & & & & \\
\hline Chrysidinae: Chrysidini & Chrysis splendidula Rossi, 1790 & 4 & & 1 & & 2 \\
\hline Chrysidinae: Chrysidini & Chrysis subsinuata Marquet, 1879 & 3 & 1 & 1 & 2 & \\
\hline Chrysidinae: Chrysidini & Chrysis taczanovskii Radoszkowski, 1876 & 3 & 2 & 17 & 2 & 4 \\
\hline Chrysidinae: Chrysidini & Chrysis terminata Dahlbom, 1854 & 16 & 4 & 10 & 2 & 5 \\
\hline Chrysidinae: Chrysidini & Chrysis viennensis Linsenmaier, 1959 & & & & & 1 \\
\hline Chrysidinae: Chrysidini & Chrysis viridula Linnaeus. 1761 & 6 & 3 & 10 & 3 & 1 \\
\hline Chrysidinae: Chrysidini & Chrysura austriaca (Fabricius, 1804) & 2 & & & 1 & \\
\hline Chrysidinae: Chrysidini & Chrysura cuprea (Rossi, 1790) & 7 & 5 & 12 & 11 & 1 \\
\hline Chrysidinae: Chrysidini & Chrysura dichroa (Dahlbom, 1854) & 22 & 6 & 9 & 15 & 4 \\
\hline Chrysidinae: Chrysidini & Chrysura filiformis (Mocsáry, 1889) & 4 & 1 & 2 & 1 & 1 \\
\hline Chrysidinae: Chrysidini & Chrysura hirsuta (Gerstaecker, 1869) & & & 1 & & \\
\hline Chrysidinae: Chrysidini & Chrysura radians (Harris, 1776) & 2 & & & 1 & 1 \\
\hline Chrysidinae: Chrysidini & Chrysura simplex (Dahlbom, 1854) & & & & & 2 \\
\hline Chrysidinae: Chrysidini & Chrysura trimaculata (Förster, 1853) & 6 & 3 & 7 & 2 & 1 \\
\hline Chrysidinae: Chrysidini & Euchroeus purpuratus (Fabricius, 1787) & 4 & & & & 1 \\
\hline Chrysidinae: Chrysidini & Pseudospinolia neglecta (Shuckard, 1836) & 9 & 1 & 13 & 6 & 4 \\
\hline Chrysidinae: Chrysidini & Pseudospinolia uniformis (Dahlbom, 1854) & 2 & & 2 & 3 & \\
\hline Chrysidinae: Chrysidini & Spinolia unicolor (Dahlbom, 1831) & 1 & 1 & & 1 & \\
\hline Chrysidinae: Chrysidini & Spinolia dallatorreana Mocsáry, 1896 & 1 & & & & 2 \\
\hline Chrysidinae: Chrysidini & Trichrysis cyanea (Linnaeus, 1761) & 41 & 16 & 25 & 6 & 13 \\
\hline Parnopinae & Parnopes grandior (Pallas, 1771) & 2 & 7 & & 3 & 1 \\
\hline
\end{tabular}


2. táblázat: A Chrysididae fajok elterjedési jellegének százalékos megoszlása tájanként

\begin{tabular}{|c|c|c|c|c|}
\hline elterjedési jelleg & 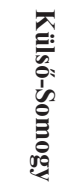 & 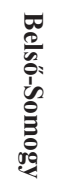 & 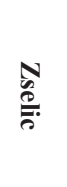 & $\begin{array}{l}\frac{2}{2} \\
\frac{2}{2} \\
\frac{2}{2}\end{array}$ \\
\hline Palearktikus & 31,8 & 32,9 & 31,5 & 37,5 \\
\hline Nyugat-Palearktikus & 17,9 & 20 & 20,5 & 15,4 \\
\hline Pontomediterrán & 27,5 & 24,8 & 26,1 & 23,3 \\
\hline Holomediterrán & 3,8 & 5,9 & 2,7 & 5,3 \\
\hline Mediterrán & 6,7 & 7 & 9,6 & 9,3 \\
\hline Kelet-mediterrán & 4,8 & 4,8 & 4,1 & 3,9 \\
\hline Észak-mediterrán & 2,8 & 2,3 & 2,7 & 2,7 \\
\hline Pontusi & 0,9 & 0 & 0 & 0 \\
\hline Európai & 1,9 & 2,3 & 1,4 & 1,3 \\
\hline Közép-európai & 1,9 & 0 & 1,4 & 1,3 \\
\hline Összesen: & 100 & 100 & 100 & 100 \\
\hline
\end{tabular}

3. táblázat: A Chrysididae fajok ökofaunisztikai jellegének százalékos megoszlása tájanként

\begin{tabular}{|c|c|c|c|c|}
\hline ökofaunisztikai jelleg & 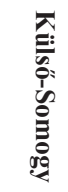 & 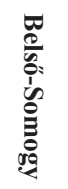 & $\begin{array}{l}\text { N } \\
\stackrel{0}{0} \\
\frac{0}{2}\end{array}$ & $\begin{array}{l}\frac{2}{2} \\
\frac{2}{8} \\
\frac{0}{2}\end{array}$ \\
\hline stenoök eremophil & 10,4 & 7,1 & 2,7 & 5,2 \\
\hline euryök eremophil & 69,5 & 71,8 & 76,7 & 76,4 \\
\hline hypereuryök intermedier & 10,5 & 12,9 & 13,8 & 11,7 \\
\hline euryök hylophil & 9,6 & 8,2 & 6,8 & 6,7 \\
\hline összesen & 100 & 100 & 100 & 100 \\
\hline
\end{tabular}

4. táblázat: Az egyes tájak Chrysididae faunájának hasonlósága a Jaccard index szerint

\begin{tabular}{|l|c|c|c|c|}
\hline & Külső-Somogy & Belső-Somogy & Zselic & Mecsek \\
\hline Külső-Somogy & $\mathrm{x}$ & 0,72 & 0,67 & 0,7 \\
\hline Belső-Somogy & 0,72 & $\mathrm{x}$ & 0,69 & 0,65 \\
\hline Zselic & 0,67 & 0,69 & $\mathrm{x}$ & 0,73 \\
\hline Mecsek & 0,7 & 0,65 & 0,73 & $\mathrm{x}$ \\
\hline Összesen & 100 & 100 & 100 & 100 \\
\hline
\end{tabular}


5. táblázat: Az egyes növények virágait látogató Chrysididae fajok száma

\begin{tabular}{|c|c|}
\hline Umbelliferae & fajszám \\
\hline Aegopodium podagraria & 6 \\
\hline Aethusa cynapium & 2 \\
\hline Anethum graveolens & 2 \\
\hline Angelica sylvestris & 28 \\
\hline Anthriscus sylvestris & 6 \\
\hline Apium graveolens & 1 \\
\hline Conium maculatum & 9 \\
\hline Daucus carota & 17 \\
\hline Eryngium campestre & 6 \\
\hline Falcaria vulgaris & 13 \\
\hline Heracleum sphondylium & 15 \\
\hline Levisticum officinale & 2 \\
\hline Pastinaca sativa & 25 \\
\hline Peucedanum spp. & 2 \\
\hline Phoeniculum vulgare & 12 \\
\hline Pimpinella saxifraga & 1 \\
\hline Seseli spp. & 12 \\
\hline Silaum peucedanoides & 2 \\
\hline Sium erectum & 2 \\
\hline Torilis arvensis & 1 \\
\hline \multicolumn{2}{|l|}{ Asteraceae } \\
\hline Matricaria inodora & 9 \\
\hline Stenactis anпиа & 5 \\
\hline Anthemis austriaca & 3 \\
\hline Achillea millefolium & 10 \\
\hline Achillea pannonica & 3 \\
\hline Helichrysum bracteatum & 1 \\
\hline Solidago gigantea & 3 \\
\hline Centaurea micranthos & 1 \\
\hline Anthemis cotula & 4 \\
\hline Anthemis tinctoria & 1 \\
\hline Chrysanthemum leucanth. & 1 \\
\hline
\end{tabular}

\begin{tabular}{|c|c|}
\hline Labiatae & fajszám \\
\hline Thymus spp. & 8 \\
\hline Marrubium peregrinum & 7 \\
\hline Mentha longifolia & 1 \\
\hline Lamium purpureum & 2 \\
\hline \multicolumn{2}{|l|}{ Euphorbiaceae } \\
\hline Euphorbia cyparissias & 12 \\
\hline Euphorbia marginata & 10 \\
\hline Euphorbia palustris & 2 \\
\hline Euphorbia salicifolia & 3 \\
\hline Euphorbia seguierana & 1 \\
\hline \multicolumn{2}{|l|}{ Egyéb család } \\
\hline Berteroa incana & 2 \\
\hline Campsis radicans & 1 \\
\hline Dorycnium germanicum & 3 \\
\hline Gypsophila paniculata & 5 \\
\hline Jasione montana & 1 \\
\hline Knautia arvensis & 1 \\
\hline Limonium sinuatum & 4 \\
\hline Linum austriacum & 1 \\
\hline Linum perenne & 1 \\
\hline Moenchia mantica & 1 \\
\hline Ornithogalum umbell. & 1 \\
\hline Potentilla argentea & 1 \\
\hline Ranunculus sp. & 1 \\
\hline Salix cinerea & 1 \\
\hline Scabiosa ochroleuca & 1 \\
\hline Sedum acre & 4 \\
\hline Spiraea sp. & 1 \\
\hline Symphytum officinale & 1 \\
\hline Tilia cordata & 1 \\
\hline Trifolium arvense & 2 \\
\hline Veronica chamaedrys & 1 \\
\hline Veronica spicata & 1 \\
\hline Vicia sp. & 1 \\
\hline Viola arvensis & 1 \\
\hline
\end{tabular}




\section{Irodalom}

JózAN Zs. 1992a: A Boronka-melléki Tájvédelmi Körzet fullánkos hártyásszárnyú (Hymenoptera, Aculeata) faunájának alapvetése. - Dunántúli Dolgozatok Természattudományi Sorozat: 7: 163-210.

JózAN Zs. 1992b: A Zselic darázsfaunájának (Hymenoptera, Aculeata) állatföldrajzi és ökofaunisztikai vizsgálata. - Somogyi Múzeumok Közleményei 9: 279-292.

JózAN Zs. 1994(1998): A Bakony fémdarázs faunájának (Hymenoptera, Chrysididae) alapvetése. - Folia Musei Historico-Naturalis Bakonyiensis 13: 117-134.

JózAn Zs. 1998: A Duna-Dráva Nemzeti Park fullánkos hártyásszárnyú (Hymenoptera, Aculeata) faunája. Dunántúli Dolgozatok Természettudományi Sorozat 9: 291-327.

JózAN Zs. 2000: A Villányi-hegység fullánkos hártyásszárnyú (Hymenoptera, Aculeata) faunája. - Dunántúli Dolgozatok Természettudományi Sorozat 10: 267-283.

JózAN Zs. 2001: Somogy megye fullánkos hártyásszárnyú (Hymenoptera, Aculeata) faunája. - Natura Somogyiensis 1: 269-293.

JózAN Zs. 2002: Az Örség és környéke fullánkos hártyásszárnyú faunájának alapvetése (Hymenoptera, Aculeata). - Praenorica folia historico-naturalia 6: 59-96.

JózAN Zs. 2003: A Látrányi Puszta Természetvédelmi Terület fullánkos hártyásszárnyú (Hymenoptera, Aculeata) faunája. - Natura Somogyiensis 5: 209-233.

JózAN Zs. 2006: A Mecsek fullánkos hártyásszárnyú faunája (Hymenoptera, Acueata). - Folia Comloensis 15: 219-238.

JóZAN Zs. 2015: A Barcsi borókás fullánkos faunája, III. (Hymenoptera: Aculeata) - Natura Somogyiensis 26: 95-108.

JózAN Zs. 2017: A balatonfüredi Tamás-hegy fullánkos hártyásszárnyú (Hymenoptera, Aculeata) faunája. Natura Somogyiensis 30: 47-69.

MóczÁR L. 1967: Fémdarázsalkatúak - Chrysidoidea - In: Magyarország Állatvilága (Fauna Hungariae) XIII/2: 1-118.

Muskovits J., RAhmé N. \& SzőKe V.: Magyarország fémdarazsai (Hymenoptera, Chrysididae). - (kézirat) 
